\title{
Spirituality And Music Education
}

\section{Call for papers}

\section{1st International Conference on Spirituality and Music Education (SAME)}

18th - 20th June 2010

Crescent Theatre Birmingham UK

You are invited to submit papers for this conference on any aspects of spirituality and music education.

The deadline for abstracts is 15th January 2010. Abstracts should be between 200-300 words and be accompanied by a short biography (100 words) on a separate sheet. All papers will be peer reviewed and acceptance as a paper or poster notified by the end of February. Abstracts and biographies should be sent via the website www.spirituality4mused.org and you will be notified when they are received. Further details about the conference can also be found on this website. 


\section{CAMBRIDGE}

\section{JOURNALS}

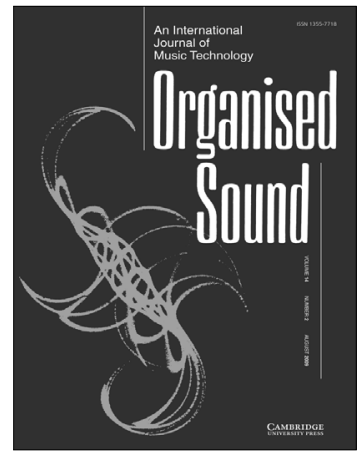

Organised Sound

is available online at:

http://journals.cambridge.org/oso

To subscribe contact

Customer Services

in Cambridge:

Phone $+44(0) 1223326070$

Fax $+44(0) 1223325150$

Email journals@cambridge.org

\section{in New York:}

Phone +1 (845) 3537500

Fax +1 (845) 3534141

Email

subscriptions_newyork@cambridge.org

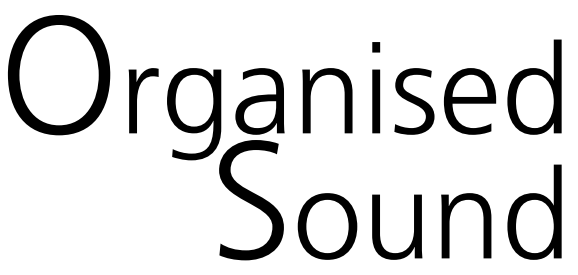

An International Journal of Music and Technology

\section{Editor}

Leigh Landy, De Montfort University, Leicester, UK

This international peer-reviewed journal focuses on the rapidly developing methods and issues arising from the use of contemporary technology in fields such as multimedia, performance art, sound sculpture and electroacoustic composition.

\section{Price information is available at: http://journals.cambridge.org/oso}

\section{Free email alerts}

Keep up-to-date with new material - sign up at http://journals.cambridge.org/alerts 


\section{CAMBRIDGE}

\section{JOURNALS}

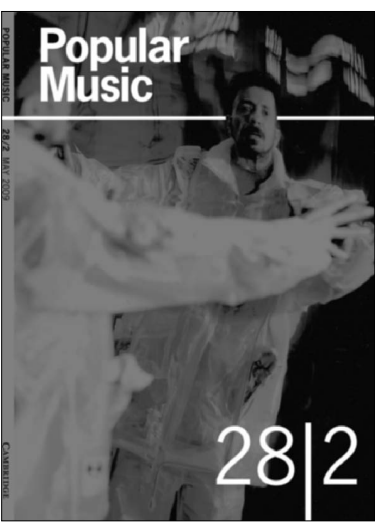

\section{Popular Music}

is available online at:

http://journals.cambridge.org/pmu

To subscribe contact

\section{Customer Services}

\section{in Cambridge:}

Phone +44 (0)1223 326070

Fax $+44(0) 1223325150$

Email journals@cambridge.org

\section{in New York:}

Phone +1 (845) 3537500

$\mathrm{Fax}+1(845) 3534141$

Email

subscriptions_newyork@cambridge.org
Popular

Music

\section{Co-ordinating Editors}

Nicola Dibben, University of Sheffield, UK Keith Negus, University of London, UK

Popular Music is an international multi-disciplinary journal covering all aspects of the subject from the formation of social group identities through popular music, to the workings of the global music industry, or how particular pieces of music are put together. Relating to any kind of popular music, the journal carries articles by scholars from a large variety of perspectives.

Price information is available at: http://journals.cambridge.org/pmu

Free email alerts

Keep up-to-date with new material - sign up at http://journals.cambridge.org/alerts
For free online content visit: http://journals.cambridge.org/pmu
CAMBRIDGE UNIVERSITY PRESS 


\section{BRITISH JOURNAL OF MUSIC EDUCATION}

\section{Instructions for Authors}

The British Journal of Music Education is a fully refereed international journal which aims to present clear and stimulating research on all aspects of music education.

\section{Contacting the Editorial office}

Editorial correspondence, including manuscripts for submission, should be addressed to:

The Journal Administrator, Alison Buckler, Faculty of Education and Language Studies, Stuart Hall Building,

The Open University, Milton Keynes MK7 6AA, UK

Email: A.S.Buckler@open.ac.uk

Book reviews should be sent to:

Dr Stephanie Pitts, Department of Music, University of Sheffield, The Jessop Building, 34 Leavygreave Road,

Sheffield S3 7RD, UK

Email: s.e.pitts@sheffield.ac.uk

Articles must not previously have been published or be submitted simultaneously for review elsewhere. Contributors are responsible for obtaining and acknowledging copyright permissions where necessary. Authors of articles published in the journal assign copyright to Cambridge University Press.

\section{Manuscript preparation}

Articles should usually be around 5,000 words long, but shorter research notes or more substantial pieces will be considered. Authors should provide a word count at the end of the article. All hard copy must be typed double spaced on A4 or equivalent, with generous margins and numbered pages. The author's name should be given on a separate sheet to facilitate anonymous refereeing.

An abstract of about 100 words summarizing the contents of the article should be typed immediately below the title and above the main text. A note giving details of any acknowledgements should also be included. Author's name(s), postal address(es) and affiliation(s) should be submitted on a separate cover sheet, together with a 75-word biographical note outlining principal publications and relevant achievements/experience.

Writing should be clear and jargon free; subheadings are helpful in long articles. All forms of racial and gender stereotyping must be avoided. The journal has an international readership, so all abbreviations and acronyms should be given in full at their first mention, and school years/pupil ages clearly defined.

\section{Quotations and references}

Within the text give author, date and page in brackets, e.g. '(Paynter, 1992: 33)', and list all references alphabetically by surname on a separate sheet at the end. Please note: 'Eds' without point; ' $\&$ ' for joint authors or publishers. For books: surname, initials, publication date (in brackets), title (in italics), place of publication, publisher. For articles: surname, initials, publication date (in brackets), full title (not in italics), journal title (in italics), volume number, issue number, page number(s). For articles in books : author's name, publication date (in brackets), title (in quotes) 'in' editor's name, book title (in italics), place of publication, publisher.

\section{Illustrations and musical examples}

All non-text material should be of the highest quality possible for reproduction. Photographs and diagrams should be numbered consecutively as figures and listed on a separate sheet. These may be line drawings or photographs. Electronic files of figures should ideally be saved as TIFF or EPS files and scanned images done at a minimum of 320 dpi. Musical examples and video are also welcomed for inclusion and will appear as supplementary material alongside the electronic version of the article on Cambridge Journals Online. These should be submitted in a standard file format and should not normally exceed 10MB. AAC files are preferred for audio examples, and MP4 files for video examples. All files should be clearly labelled.

\section{The review process}

Submitted articles will be sent out to two reviewers and a decision (accept/revise/reject) reached by the editors, usually within three months. Articles accepted must then be submitted by email, conforming to the journal's house style. The preferred word processing packages are Word or WordPerfect in either PC or Macintosh format and the preferred graphics package is Freehand. Authors will be sent proof copies, at which stage typographical or factual errors only may be changed. Contributors of articles will receive a pdf of their article without charge. Extra offprints may be purchased at first proof stage.

\section{More detailed instructions for authors are available on request from the editors, or on the BJME website: journals.cambridge.org/bme}

This journal issue has been printed on FSC-certified paper and cover board. FSC is an independent, non-governmental, not-for-profit organization established to promote the responsible management of the world's forests. Please see www.fsc.org for information.

Printed in the United Kingdom by the University Press, Cambridge 


\section{British Journal of Music Education}

\section{Volume 26 Number 3 November 2009}

\section{CONTENTS}

The Contributors

Editorial

Articles

Stephanie Pitts: Roots and routes in adult musical participation: investigating the impact

of home and school on lifelong musical interest and involvement

Jonathan Lilliedahl and Eva Georgii-Hemming: Parental expectations of the Swedish municipal schools of arts

Niklas Pramling: External representation and the architecture of music: Children inventing and speaking about notations

Allan Hewitt: Student musicians' self- and task-theories of musical performance:

the influence of primary genre affiliation

Andrea Creech, Helena Gaunt, Susan Hallam and Linnhe Robertson: Conservatoire students' perceptions of Master classes

\section{Book Reviews}

Marie McCarthy: International Handbook of Research in Arts Education

edited by Liora Bresler

Eve Harwood: Musician and Teacher: An Orientation to Music Education

by Patricia Shehan Campbell

Nicola Dibben: Gender in the Music Industry: Rock, Discourse and Girl Power

by Marion Leonard

Tim Cain: Music Education with Digital Technology edited by John Finney

\& Pamela Burnard

Jonathan Savage: Computers in Music Education: Amplifying Musicality

by Andrew R. Brown

Cambridge Journals Online For further information about this journal please go to the journal website at: journals.cambridge.org/bme

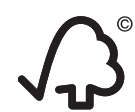

Mixed Sources

Product group from well-managed forests and other controlled sources

FSC www.fsc.org Cert no. SA-COC-1527
CAMBRIDGE UNIVERSITY PRESS 